\title{
Remembering and Forgetting the Last War: Discursive Memory of the Sino- Vietnamese War in China and Vietnam
}

\author{
Qingfei Yin* and Kosal Path** \\ *Department of History, Virginia Military Institute, USA \\ Corresponding author. E-mail: yinq@,vmi.edu \\ **Department of Political Science, Brooklyn College, City University of New York, USA
}

\begin{abstract}
The year 2019 marked the 40th anniversary of the outbreak of the Sino-Vietnamese War in 1979. Making use of published and unpublished Chinese, Vietnamese, and English sources, this article traces the tensions between official and popular memories of the Sino-Vietnamese War of 1979 in China and Vietnam, respectively. We argue that these tensions existed because the development of the official Chinese and Vietnamese memories of the war largely mirrored each other. Between 1991 and roughly 2006, when bilateral relations between the countries improved, both Beijing and Hanoi claimed victory for their side while simultaneously downplaying the bloodshed, tragedy, and loss experienced during the war. However, they have reacted to the rise of popular memories since the early 2000s in very different ways. While Beijing walks a thin line between accommodating appeals for greater recognition of the sacrifices made by ordinary soldiers without provoking social discontent with the political system, Hanoi has been more successful in mobilising Vietnamese popular memory of the war to strike a measured nationalistic response to China. How China and Vietnam remember and downplay the SinoVietnamese War points to the bigger picture of the sensitivity of bilateral relations to historical memory in Asia. In particular, historical memory shapes how a country perceives external threats and opportunities, while historical memory is created, suppressed, and re-created as international relations evolve.
\end{abstract}

Keywords: Historical Memory, Third Indochina War, Sino-Vietnamese Border War, China, Vietnam 


\section{Introduction}

The 40th anniversary of the Sino-Vietnamese War in 1979 fell on 17 February 2019. Forty years ago, the People's Liberation Army (PLA) of China entered Vietnam along the length of the border in an invasion that surprised the world (Middleton 1979: 1). While the PLA withdrew from Vietnam in March 1979, the armed confrontation at the Sino-Vietnamese border lasted for another decade, forming a major frontline of the Third Indochina War between Vietnam, China, and Cambodia (1979-88). Throughout the 1980s, China and Vietnam - the two previously fraternal nations - engaged in "a marathon conflict" (Hood 1992: xv) while economic development gaining salience on the political agenda for both sides.

This article traces the tensions between official and popular memories of the SinoVietnamese War of 1979 in China and Vietnam, respectively. We argue that these tensions existed because the development of the official Chinese and Vietnamese memories of the war largely mirrored each other. Between 1991 and roughly 2006, when bilateral relations between the countries improved, both Beijing and Hanoi claimed victory for their side while simultaneously downplaying the bloodshed, tragedy, and loss experienced during the war. However, they have reacted to the rise of popular memories since the early 2000 s in very different ways. While Beijing walks a thin line between accommodating appeals for greater recognition of the sacrifices made by ordinary soldiers without provoking social discontent with the political system, Hanoi has been more successful in mobilising Vietnamese popular memory of the war to strike a measured nationalistic response to China.

More specifically, the formation and development of the official memories of the Third Indochina War in China and Vietnam are comparable and contextually intertwined. As the war took place against the backdrop of economic reform and a political climate questioning the Maoist legacy in China, both the patriotism of the fighters and the difficulties caused by past mistakes of the Chinese Communist Party (CCP) found a place in the official Chinese narrative of the war. By contrast, the Vietnamese state created a heroising narrative of the war by presenting it as a glorious victory against China, fearing that releasing details about the conflict would invite public criticism of the Vietnamese military's blunders and threaten the legitimacy of the ruling party. The Vietnamese people have generally uncritically embraced this statesanctioned memorialisation because it suits their collective memory of having a long history of 
resisting imperial China. After the normalisation of China and Vietnam's bilateral relations in 1991, both governments - especially Beijing - reduced their publicity of the war. Paul Connerton (2008: 61) characterises such actions precipitated by states in the belief that not remembering past wrongs is in the best interests of all parties previously involved in a dispute as "prescriptive forgetting."

However, discursive popular memories about the conflict in China and Vietnam constitute a 'vernacular resistance' against the respective countries' official histories. Veterans and cyber-nationalists in both countries, for instance, have shifted the public attentions away from the officially endorsed recollections of wise decisions having been made by the party leadership to focus instead on the sacrifice and loss experienced and remembered by actual soldiers. The two states, however, have reacted to the mounting vernacular resistance differently. Beijing's concern has been that bringing up the memory of the Sino-Vietnamese War would instigate veteran activism and further undermine social stability. By contrast, Vietnam made a strategic decision to allow its country's intellectuals, state-sponsored media outlets, and social rituals to memorialise the war in a nationalistic and heroic way that serves to legitimise the Communist Party of Vietnam (CPV) as the vanguard of the Fatherland (to quoc) in reaction to China's recent assertiveness in the South China Sea, or what the Vietnamese call the East Sea (Bien Dong), while avoiding accusations of provoking anti-China sentiment.

These differences manifested in how the two countries commemorated the 40th anniversary of the war. The Vietnamese state media, the Vietnam News Agency (2019), lauded the war as proof of "the sound political and military policies, and the sharp and skillful strategic leadership" of the CPV. By contrast, whereas a few posts were made in remembrance of the war by scholars and veterans on social media, such as on WeChat and Weibo, ${ }^{1}$ Chinese media (which are under tight government control) mostly remained silent. This reflects how the SinoVietnamese War has been remembered, downplayed, and re-remembered differently in China and Vietnam in the 40 years since its outbreak.

\footnotetext{
${ }^{1}$ WeChat (Weixin) is a Chinese multi-purpose messaging, social media, and mobile payment app developed by Tencent. As of 2018, it has one billion monthly active users. Weibo is a microblogging website that was launched in 2009 and has 340 million active accounts. A widely reposted article was written by the son of a Chinese soldier who died during the war titled "Duiyue ziwei fanjizhan 40 nian, ni shifou xiangxin wo huazuole shanmai" [40 years after the self-defence war against Vietnam, do you believe that I become part of the mountain], 16 February 2019, available at: https://mp.weixin.qq.com/s/zO1QoSmb4qm2FRvihs5xBA (accessed 17 February 2019).
} 


\section{Contextualisation and the Existing Literature on the Sino-Vietnamese War}

The Third Indochina War was the last major international conflict involving China and Vietnam. At the time that the war broke out in the late 1970s, China and Vietnam's relations with the great powers were perilous and the drastic changes taking place in the domestic politics of the two countries created instability (Chen 1987; Duiker 1986; Ross 1988). While Vietnam's toppling of the Khmer Rouge regime directly triggered Beijing's decision to invade Vietnam, Andrew Mertha (2014: 3) points out that China received "little tangible benefits from" its support of the Communist Party of Kampuchea. China's involvement in the Third Indochina War had a profound impact on its relations with the great powers. As Nicolas Khoo (2011: 11-12) argues, the collapse of the Sino-Vietnamese partnership was "collateral damage" of rapidly deteriorating Sino-Soviet relations. Domestically, Deputy Prime Minister Deng Xiaoping, who held real power in the country, used the war to further his modernisation agenda. An anti-Soviet/antiVietnamese policy helped expand China's economic and technological ties with the Western world, especially the United States (Zhang 2015: 6-9). On the other hand, the Vietnamese leaders, as Sophie Quinn-Judge argues, possessed a “"big brother' complex” born of their experience of leading communist revolutions in Indochina. The Vietnamese invasion of Cambodia brought the country victory on the battlefield yet led to isolation in Asia (Quinn-Judge 2006: 207-214). The strategic calculations behind Beijing's and Hanoi's belligerence also shaped their state-sanctioned memories of the conflict as both justified personal sacrifice as being in the best interests of the nation.

Although China and Vietnam claimed victory after the war in 1979, both actually fared poorly on the battlefield. Xiaoming Zhang (2015: 109) points out that China's sudden and massive assaults caught Hanoi off guard and successfully obscured the Vietnamese high command's understanding of Beijing's real objectives; the PLA, however, "was overextended, obsolescent, ill-trained, and poorly equipped." It had also lost the respect of the Chinese people due to its abuse of power during the Cultural Revolution. The inefficiency of the PLA, according to Edward O'Dowd (2007: 6-10), prevented China from achieving the goal of inducing Vietnam to withdraw from Cambodia. The poor performance of both the PLA and the People's Army of Vietnam and the bloodshed caused as a result of the conflict have left a permanent mark on how the two societies remember it. 
This paper builds upon the existing scholarship on the politics of memory in China and Vietnam. Both the CCP and the CPV have long aimed to use the past as a way of strengthening the legitimacy of their regimes among the younger generations. The Chinese government has used history education, especially the notion of "one hundred years of national humiliation", to "glorify the party, reestablish its legitimacy, consolidate national identity, and justify one-party rule in the post-Tiananmen and post-Cold War era" (Wang 2012: 9). However, mobilising historical memory for political purposes must strike a delicate balance, as it can entrap national leaders in conflict memory and therefore constrain foreign policy. The Chinese government has to balance the attempt to foster a nationalism deemed 'healthy' among the younger generation and to deal with the "rather loud and uncompromising expression of this nationalism online" (Bislev 2014: 117). Meanwhile, China is pulled between "an old socialist discourse and a new market ideology": Toeing the official communist line and strengthening the party's hold over society during the market-oriented reform has led to the production of "ideologically ambiguous space[s]" such as museums (Denton 2014: 9).

The Vietnamese state faces a similar challenge. The main debate in the existing scholarship on Vietnamese memories of the 1979 border war is between "political civil society" (Vu 2014: 41) and traditional state-centric perspectives. Tuong Vu (2014: 33-66) argues that Vietnam's economic reforms and opening (doi moi) over the past two decades have led to the birth of a political civil society consisting of diverse yet disorganised social groups including exparty officials, military officers, and bloggers. Aided by social media and emboldened by the decline of ideological appeal, this civil society not only challenges the party's hegemonic control over the nation's collective memory but also pushes the party to take a tougher stance against China. Like Vu, Martin Grossheim (2018: 147-180) claims that after the 1991 normalisation of Sino-Vietnamese relations, Hanoi downplayed commemorations of the war, and domestic forces - especially the intelligentsia and public - drove the government to allow more detailed accounts of the 1979 Sino-Vietnamese War to be published in history textbooks. Although we agree with Grossheim regarding Hanoi's suppression of public commemoration of the conflict after 1991, the memory of the conflict has been kept alive at the academic level and in Vietnamese society as a whole. We challenge the claim that the Vietnamese academy could somewhat independently shape the public's memory of the war. 
Other scholars share a common view that historical enquiry and writing in Vietnam continues to be constrained by the official metanarrative, which is "an exclusive conception of history that denies the pluralism of the human experience" (Giebel 2007: 319). They stress the power of the Vietnamese state to construct war memories as it sees fit. Hue-Tam Ho Tai (2001: 177) wrote: "In the two decades since the [Vietnam] war ended, the Vietnamese state has tried to shape collective memory to underline the continuity between the Revolution and the War Against the Americans, on the one hand, and past struggles for national independence, on the other". Shaun Kingsley Malarney (2001: 47) further points out Hanoi's attempt to "draw on the prestige that has historically accrued to those who protected the country from foreign aggression or liberated it from foreign occupation”. Christoph Giebel (2007: 308, 319) mainly attributes Hanoi's fixation on its wartime past to its desire to ramp up "constant public reminders of military heroism in response to the ever increasing lure of commercialism and materialism on Viet Nam's increasingly apolitical youth". Building on these works, we contend that the Communist Party-led Vietnamese state remains the predominant gatekeeper of historical memory despite the fact that actors besides the state have been able to make use of memory space over the past three decades.

While the existing literature on how the Chinese and Vietnamese Communist parties and states have shaped their country's collective memory is very insightful, the intertwined process of their memory formation in terms of remembering the Sino-Vietnamese War has been ignored. Building upon but also challenging the existing literature, we argue that whereas the Chinese state has only reluctantly allowed its citizens' commemoration of the war to intensify under rising pressure from and initiatives led by Chinese veterans, the Vietnamese state has been more determined in managing memories of the war in order to serve its foreign policy goals. Therefore, memories of the Sino-Vietnamese War epitomise the profound changes that have taken place in the landscape of domestic politics in China and Vietnam as well as the fluctuations in Sino-Vietnamese relations.

\section{Remembering the War: 1979-1991}

The propaganda war between Beijing and Hanoi accompanied their armed conflict. It was widely believed that Beijing's decision to invade Vietnam was a response to a perceived "joint Soviet- 
Vietnamese strategy to encircle and humiliate it" following the Treaty of Friendship and Cooperation between the Soviet Union and Vietnam in June and Vietnam's invasion of Cambodia in December 1978 (Butterfield 1979: 1, 10). To gain international support, China openly disavowed having any territorial aims and justified its campaign as 'self-defence against Vietnamese aggressors' (duiyue ziwei fanjizhan). It also used the Vietnamese government's persecution and mass expulsion of Chinese residents after 1975 to tarnish Vietnam's international reputation. ${ }^{2}$ In Vietnam, the conflict has been known as the 'War of Defending the Northern Border' (Chien tranh bao ve bien gioi phia bac). Hanoi presented its military intervention in Cambodia ${ }^{3}$ and installation of a puppet regime - the People's Republic of Kampuchea - as a noble cause, immortalising Vietnam as the saviour of the Cambodian people and justifying a prolonged occupation of Cambodia based on Ho Chi Minh's teaching: "helping our Cambodian friends is helping ourselves" (giup ban la tu giup minh) (Ngo 2018: 164; Nguyen 2013: 117). Behind closed doors, once assured that it would receive more economic and military aid from Moscow, the Politburo of the CPV made a strategic decision to get rid of the Pol Pot regime and prevent China from using Cambodia as "a new colony" and "military base" from which to threaten Vietnam (QH h.s. 2354 1978; QH h.s. 2374 1979c: 22). To defend their publicly announced goals in the Third Indochina War, the central governments of China and Vietnam played an active role shaping the memories of the conflict in their respective countries.

\section{Memory Formation in China during the Conflict}

During the invasion in February and March 1979, Beijing aimed to re-establish the reputation of the PLA as a powerful force and legitimise the CCP as a pioneer of the people. The People's Liberation Army Daily extensively covered the valour of war heroes shown during combat in an attempt to reassure the public that after decades of peace, despite its soldiers' lack of fighting experience and poor training, the PLA was still able to defeat the enemy with its perseverance and battlefield tactics. The wartime propaganda often drew comparisons between PLA heroes during the Korean War and those fighting Vietnam, praising the young soldiers for "following in the footsteps of the older generations" and "continuing to write the glorious history" of their

\footnotetext{
${ }^{2}$ The persecution of ethnic Chinese, or Hoa people, started after the unification of Vietnam in 1975 and lasted throughout the 1979 border war. Between 17 March and 8 May 1979, 8000 Chinese and Vietnamese citizens were driven into Chinese territory from the three cities of Hanoi, Haiphong, and Nam Dinh. See Alley (1980).

${ }^{3}$ Note that the term 'xam luoc' (invasion) of Cambodia is prohibited from official use in Vietnam. Instead, the officially endorsed term is 'dua quan Viet Nam vao Campuchia' (entry of the Vietnamese army into Cambodia). For example, see Luu (2006: 436).
} 
combat units (Yunnan renmin chubanshe 1979: 28). Meanwhile, as the appeal of communism waned, the government had to look for alternative discourse to justify its sacrifice of the people. In state-sponsored publications, PLA soldiers were depicted as fighting bravely to avenge their fallen comrades-in-arms and to pursue military honour, instead of fighting for abstract ideological causes. Another prominent theme in Chinese propaganda was the enormous amount of military aid that China had provided to Vietnam during the Second Indochina War and blaming the Vietnamese for being 'ungrateful' for China's help (Jiangsu renmin chubanshe 1979; Yunnan renmin chubanshe 1979: 28).

As the border war turned into a decade-long confrontation, in the 1980s, Beijing found it increasingly difficult to create a coherent memory of the war that glorified the wise decisions of the CCP. The market-oriented reform that was taking place in China brought with it profound social changes. While the regime maintained its rather strong repressive capacity, its control over the cultural elites weakened. Students and intellectuals were dissatisfied with the largely state-led economic reform that benefited political elites much more than the average person (Zhao 2001: 39-52). As a result of the widespread sentiment that questioned the Maoist revolutionary legacy, especially the Cultural Revolution, the CCP tried to convince the Chinese people that despite all the difficulties the country faced (caused partially by the party's past mistakes), the PLA was still victorious thanks to the patriotism of its soldiers.

The most popular novel about the war published in the 1980s, Wreaths at the Foot of the Mountain, reflected the popular anger felt as a result of the widespread corruption. Written by Li Cunbao in 1982, the novel revealed tensions in the military between the elites and those from humble backgrounds by showing that high-ranking military officers abused their power by transferring their children in active service away from the frontlines. Some command officers turned a blind eye to the poor living conditions of those in the bomb shelters, where the soldiers had to stay in confined spaces and suffered from the heat, the humidity, and shortages of fresh water. The book highlighted the damaging legacy of the Cultural Revolution, as weapons often malfunctioned due to their poor maintenance over the previous decade ( $\mathrm{Li} 1982$ ). The novel was widely acclaimed for its uncompromising criticism of the authorities. Literary critics lauded the novel for revealing "malpractice in the military, especially among the high-ranking officers" (Tian 1985: 35), bureaucratism in the government, and highlighting the increasing tensions between the party and the masses (Chen 1983: 77-78). In 1984, the state-owned Shanghai Film 
Studio made the novel into a movie with the same title. Unlike previous war films that exclusively focused on the military talents of the party elites, the brutality of the enemy, and the bravery of Chinese soldiers, this film depicted the bloodshed, loss, and suffering. Some college students in Shanghai opined that while the heroes shown in previous movies were emotionless, the characters in Wreaths at the Foot of the Mountain all had lively temperaments. These students blamed "the dire disaster the leftist political line brought to our country and nation" for causing the unnecessary loss of life during the war and warned that "toeing such a line still poison[ed] some people's minds" (Xiao 1984: 78).

Chinese society also questioned the pervasive collectivist culture that called for its total devotion to and sacrifice for the proletarian revolution at any cost and deemed the expression of individual desires and fears legitimate in its memorialisation of the Sino-Vietnamese conflict. Even military-sponsored publications had a strong personal touch. In a collection of soldiers' personal correspondence from the Battle of Laoshan (or the Battle of Vi Xuyen, in Vietnamese) in 1984, for instance, readers could find letters from a worried father asking his son to "decimate the enemy but also protect yourself", letters from a young private missing his family when he fell victim to food poison and hunger, and letters from the young wife of a sergeant complaining about her hard life at home (Zhongguo renmin jiefangjun 35151 budui zhengzhibu 1986: 58-61, 108).

At the local level, the war was simultaneously a victory and a tragedy for those people who experienced the bloodshed in the border provinces of Guangxi and Yunnan. The PLA relied heavily on the local people to "support the front" (zhiqian) during its invasion of Vietnam in 1979. Militia in border counties assisted the PLA by guiding the troops on mountainous trails, serving as translators, building fortifications, transporting food and daily necessities for the soldiers, and rescuing the wounded (FCDA no. 1-2-455-13 1979: 38-44). The war was a heavy blow to local communities. By the early 1980s, most parts of China had begun to benefit from the economic reforms launched in 1978; agriculture was de-collectivised, coastal areas opened up for foreign investment, and entrepreneurs were permitted to start businesses. This transformation from political struggle to economic growth, however, was significantly delayed in the areas of China that bordered Vietnam. During the 1979 border war, Chinese border counties were required to "fight while producing", meaning they needed to increase the supply of food to the military despite losing arable land to shelling and mining (FCDA no. 1-2-455-13 1979: 43). 
The war also deindustrialised border towns as factories were relocated to avoid bombardment (Nong 2015: 194). Besides the economic recession it caused on a local level, border communities remembered the Sino-Vietnamese War as a tragedy due to the injuries and deaths continuously caused as a result of landmines. From the end of 1975 to 1985, China and Vietnam planted more than 100 million landmines in around 400 minefields along the border (Nong 2015: 157). The landmines threatened border villagers' lives on a daily basis and became a physical reminder of death associated with the war. In the year 1985 alone, seven people in the border town of Pingxiang, which had been on the frontlines of the Sino-Vietnamese War, were killed and 25 were wounded by landmines (Nong 2015: 157). In the highlands, in Malipo County in Yunnan, an area populated by ethnic Miao, the threat of landmines was particularly severe because heavy rains could flush the landmines out of identified minefields and into farmland worked by villagers (Pengpai Xinwen 2017).

Many Chinese soldiers who fought in the Sino-Vietnamese War of 1979 and the following decade-long confrontation also remember the conflict as a tragic personal loss because they failed to benefit from the economic reform in the same way as their civilian peers. From 1984 to 1989, Beijing sent troops from different military zones in the country to the frontlines in Yunnan to fight over several strategic points with Vietnam and to let the PLA regain some battle experience through rotation (Zhang 2015: 149-153). The war, therefore, caught many soldiers unprepared. It was not uncommon for a soldier's fiancée to end their engagement after he was sent to fight in the war. In the reform era, many young women preferred to settle down with someone with a more promising future (Jin et al. 1990: 62-64, 210-227). Fu Jianren, a military writer, lamented the following:

This is not the first time we fight a war while enjoying domestic peace [after 1949]. We fought the war of resisting America and assisting Korea right after our liberation and the Sino-Indian border war in 1962. Soldiers back then were never reluctant to join the war out of concerns that their family would not be as wealthy as their neighbours .... We have lived in peace for too long, which dampens peoples' political enthusiasm. The waning enthusiasm further compromises the sense of glory associated with safeguarding the country. (Fu 1991: 7)

While Deng Xiaoping launched the Sino-Vietnamese War to push forward the post-Maoist reform (Zhang 2015), the reform shaped people's memories of war in ways that the Chinese state 
had not expected. While the official narrative that the war was a great victory went largely unchallenged, the political climate was tolerant enough that people-including those associated with the state-were able to expose the military blunders and tragic losses they had experienced. People's weariness of the state's political propaganda and their general discontent with the political system formed the undercurrents of the collective memory of the war in China.

\section{Memory Formation in Vietnam during the Conflict}

From 1979 to 1990, the Vietnamese government was more successful than the Chinese government in terms of controlling how its people remembered the war. Immediately after the Chinese invasion in February 1979, Hanoi articulated the narrative of Vietnam's heroic resistance against Chinese aggression to perpetuate the nation's collective memory of having fought against northern invaders for two millennia. Vietnam's victory against China and its ally - the Khmer Rouge - has been the official history of the CPV since Member of the Politburo and Minister of National Defense General Vo Nguyen Giap issued a lengthy report on behalf of the party in May 1979. Giap's report began by stressing that Vietnam's dual victory had served "to defend the motherland along the southwestern border against Cambodia" and "to defend the motherland along the northern border against China" (QH h.s. 2374 1979c: 13-34). Chairman of the Standing Committee of the National Assembly (SCNA) Truong Chinh attributed their victory to the long-standing Vietnamese national tradition of "fighting the enemy to protect the country", recalling the Vietnamese people's resistance to the aggression of Chinese dynasties in the past (QH h.s. 2374 1979a: 4).

In contrast to the official narrative, new documentary evidence reveals that Vietnam failed to foresee the swift and massive invasion by the PLA in February 1979. Vietnamese civilians in the six provinces along the border immediately paid a heavy price and blamed Hanoi's top leadership for the country's miscalculations and lack of military preparedness. According to a March 1979 report by a senior government delegation appointed by Prime Minister Pham Van Dong, almost all of the houses in villages located in the border provinces of Lao Cai, Lang Son, Cao Bang, and Mong Cai were destroyed by the invading Chinese troops. The PLA laid waste to nearly all industrial factories, equipment, and government infrastructure in Vietnam's war zone. Most bridges, roads, and railroads were blown up by the Chinese army's mines before they withdrew; nearly 7000 tons of food were taken by the Chinese as a trophy; 
material goods worth tens of millions of Vietnamese dong were lost; and an estimated 560,000 out of a total of approximately 800,000 Vietnamese people in Lang Son, Cao Bang, and Hoang Lien Son became homeless refugees (PTT h.s. 16327 1979).

Nonetheless, the heroism and foresight of the Vietnamese army was extolled in a protracted two-front war in the 1980s against China in the north and against the China-backed Cambodian resistance forces fighting the Vietnamese occupation troops in the southwest.

Evoking the country's long history of resistance against the northern aggression also allowed the Vietnamese government to mobilise the entire populace for its military-first campaign. On 5 March 1979, the SCNA issued a general mobilisation order to prepare for war. On the same day, the Government Council issued Directive 83-CP to militarise the entire population to defend the country and instituted a new regulation mandating that every citizen comply with a ten-hour workday - eight hours for production and two hours for military training or national defence duties (QH h.s. 2374 1979b: 5; Tran et al. 2014: 356). On 23 April, Major General Cao Van Khanh reported "the great victory of the Vietnamese people and army in their resistance to China's invasion" to the SCNA (QH h.s. 2374 1979b: 8).

In an attempt to glorify military service and restore military morale, Hanoi began in earnest to pay more attention to veterans and military personnel. On 24 May 1979, the SCNA awarded sixteen Ho Chi Minh Medals to military leaders for their outstanding contributions during the anti-American resistance period. Military Achievement and Combat Achievement Medals were bestowed on 10,218 soldiers from 938 units for defending the border against Cambodia and China. Two hundred and sixty-three families were awarded Resistance Medals for having many members serving in the army during the anti-American resistance period. Moreover, 91,011 cadres and soldiers in the police force and army were awarded Glorious Soldier Medals (QH h.s. 2374 1979b: 6-7). This was a notable feat on the part of the Vietnamese government to glorify military service and stood in stark contrast to its poor treatment of veterans at the end of the Second Indochina War and during the economic crisis of 1976-1977. The government's improved treatment of servicemen justified the growing intensity of its mobilisation of people and goods for war. On 25 February 1980, the Government Council granted the Ministry of Defense far-reaching authority to mobilise human and material resources in all fields and at all levels of the state apparatus (PTT h.s. 16381 1980a). In October, conscription was extended to all male citizens between the ages of 18 and 25 with the exception 
of cadres, technicians, engineers, and leaders in important economic defence sectors. The government also decided to recruit single women in rural areas between the ages of 18 and 20 to serve in the army for three years (PTT h.s. 16381 1980b).

Vietnam's official narrative of the 1979 Sino-Vietnamese border war was reproduced by "historian cadres", to borrow Tuong Vu's term, to perpetuate Hanoi's state-sponsored historiography throughout the 1980s. As Vu writes: "Vietnam's invasion and occupation of Cambodia further suggested a complex reality in which Vietnam was not always a victim of foreign powers and in which heroes and villains were not so clearly separated as in the imagination of analysts" (Vu 2007: 195, 203). Therefore, portraying the CPV as the prescient vanguard defending the Vietnamese Fatherland (the victim) against the Chinese (the aggressor) was key to Hanoi's justification of its intensive mobilisation throughout the 1980 s. Vietnamese historians wasted no time in bringing to life Vietnam's past resistance against China and drawing valuable lessons from the nation's past heroism in service of the CPV's mobilisation for war. In 1979, Phan Huy Le, a scholar of Vietnam's colonial resistance and later the nation's most prominent historian, summarised the Vietnamese people's three most important strengths in explaining their long history of resisting Chinese aggression as follows: 1) patriotism and independence-loving spirit; 2) national unity against foreign enemies; 3) intellect and innovation in the art of military resistance (Phan 1979: 155-156). In 1980, the CPV's chief theoretician, Truong Chinh, wrote the following (which continues to reverberate in Vietnamese society):

In implementing its anti-Vietnam policy, Beijing repeated the offensive strategy applied time and time again by feudal China in its history of invasions against Vietnam, namely, combining direct military offensive with rear attacks. In the $11^{\text {th }}$ century, when Vietnam was ruled by the Ly Dynasty, the Song dynasty in China, in collusion with the King of Champa, used the Cham army in incursions on Vietnam's southern border to weaken Vietnamese resistance to the Song army's attack from the north .... But the Chinese aggressors' strategies of pincer movements and pronged attacks were defeated. Recently, they were again smashed [referring to China's two-pronged attacks on Vietnam from Cambodia and southern China in 1978-1979]. (Truong 1980: 13-14)

Throughout the 1980s, the Vietnamese government strictly censored any historical writing that did not conform to the state-sponsored narrative of Vietnam's great victory in the two-front war in 1978-1979 and of the just cause the Vietnamese 'volunteer army' pursued in Cambodia 
during the decade-long conflict. The narrative became 'the truth' sanctioned by the CPV and the and state well into the 1990s, and it continues to persist. By contrast, it was more difficult for Beijing to impose a coherent, state-sanctioned 'truth' on its people because not only did liberal values gain popularity in the 1980s but the state had also started to contract as Chinese society moved toward a market economy.

\section{Downplaying the War: 1991-2000s}

Sino-Vietnamese relations began to normalise after 1991. In September 1989, Vietnam announced its decision to withdraw from Cambodia, which eased Sino-Vietnamese tensions and paved the way for the normalisation of Sino-Soviet relations as well (Niu 2013: 273-295). In November 1991, General Secretary of the Central Committee of the CPV Do Muoi and Prime Minister Vo Van Kiet visited China. In a joint communiqué, the two sides agreed to resolve their territorial disputes through negotiation and settle the issue of immigrants, which symbolised the end of a decade-long period of hostility between the two previous Cold War allies (Womack 2006: 213-224). Both governments emphasised looking forward for opportunities of cooperation instead of carrying the historical baggage of past animosity. How to consign the SinoVietnamese War to history and deal with the still fresh memories of the conflict became a sensitive issue, and from 1991 to the early 2000s, both Beijing and Hanoi tried to reduce the publicity of the war and downplay their recent hostilities to different extents.

\section{Marginalisation of War Memories in China after the 1991 Normalisation of Sino-Vietnamese Relations}

The Sino-Vietnamese War of 1979 remains "the least commemorated and memorialized of all conflicts in modern Chinese history" (Zhang 2015: 211) largely due to an intentional marginalisation of war memories in the country. While publications on the war were never banned entirely, the state ceased to use its outspoken criticism of Vietnam and heroising depictions of China's patriotic fighters during the war as a tool to boost Chinese nationalism. In 1990, for the first time since its creation in 1983, the widely viewed Lunar New Year Gala produced by the state-run Chinese Central Television did not send special greetings to the 
soldiers stationed on the frontlines in Yunnan and Guangxi. This signalled Beijing's desire to downplay the confrontation with Vietnam before the Chinese people.

In state-sponsored academic publications produced in the 1990s, while China's official narrative of the war as a victorious defence against Vietnamese aggression did not change, analyses of Sino-Vietnamese relations during the Cold War focused on the historical lessons learned from China's policy on Vietnam. In 1990, Pei Jianzhang, a former Chinese diplomat, published Diplomacy of Contemporary China, the first survey of the history of China's foreign relations after 1949. The book traced the deterioration of Sino-Vietnamese relations and defended Beijing's invasion by blaming Vietnam for persecuting and expelling overseas Chinese and invading Cambodia (Xue and Pei 1990: 268-290). In 1992, Guo Ming, who was born in Vietnam in the 1920s, later moved to China, and taught Vietnamese at a university in Guangxi, published The Evolution of Sino-Vietnamese Relations over Forty Years, a project sponsored by the National Social Science Fund of China from 1986 to 1990. In the book, the author reflected on the concept of socialist internationalism, questioning the practice of non-reciprocal resource sharing during the Maoist era (Guo 1992).

Outside of academia and in realms that were more accessible for a general audience, government control over writing about the Sino-Vietnamese War was tighter. The conflict never found a place in secondary school textbooks. In 1992, several scholars at Peking University, the country's leading research institution, started to write the first textbook on Chinese diplomatic history. The book did not cover the collapse of the Sino-Vietnamese partnership or their military conflicts in its main chapters at all. Instead, the authors merely mentioned "China's punitive counterattack in self-defence against Vietnam" in the chronicle of events listed in the appendix (Shi 1994: 386). Besides textbooks, the government removed the war from public view by restricting portrayals of the war in film and other artistic representations.

The marginalisation of memories of the Sino-Vietnamese conflict was not a result of open, thorough, and top-down censorship; rather, it was due to several concurrent factors taking place in Chinese foreign relations and society. Pursuing "larger strategies of good neighborliness and openness" (Womack 2011: 187) and seeking to move on with its restored relations with Hanoi, commemoration and even memories of the war were seen by the Chinese leadership as inconvenient historical baggage. Besides the perceived negative impacts it would have on the two countries' bilateral relationship, the depiction of China's military confrontation with 
Vietnam as a punitive act against Soviet-backed "Vietnamese regional hegemonism" (Xue and Pei 1990: 283) did not fit in the official narrative of a post-Maoist China peacefully re-engaging with the world. In almost all works on China's foreign relations published in the country from 1990 onward, the 1980s was depicted as a 'new era' that witnessed the normalisation and development of China's relations with the United States, Japan, and other industrialised countries. They lauded Chinese diplomacy for creating "a peaceful international environment for reform and opening up" (Xue and Pei 1990: 306). Moreover, a war that was claimed to have been waged in self-defence yet took the form of an invasion could hardly be justified. The very factor that drove Beijing to launch the attack - its perceived Soviet encirclement-no longer existed, so there was no longer a need to commemorate the war. Lastly, the Sino-Vietnamese conflict, while lasting for a decade, never affected the daily lives of most Chinese people in the same way that the Anti-Japanese War or the Korean War had. Since the 1980s and well into the 1990s, chasing a higher standard of living was the undisputable priority for most people. The 'unremembering' or marginalisation of memories of the Sino-Vietnamese conflict was an unsurprising result of the intertwined effects of political and social changes taking place in China at the time.

\section{Continuous Reproduction of Memory in Vietnam after the 1991 Normalisation of Sino-}

\section{Vietnamese Relations}

From 1991 to the early 2000s, although the CPV's leadership kept reiterating that the Chinese had given support to Vietnam in its earlier wars against France and the United States in a concerted effort to expand its economic ties with China in the service of doi moi, Vietnamese academics were allowed to continue writing about Vietnam's history of resistance to imperial Chinese dynasties. Although the government suppressed writing about the 1979 war and commemorating it, it did not ban either outright. From 1991 to 2006, Sino-Vietnamese relations warmed significantly with eleven visits by the general secretaries of the two Communist Parties, seven visits by the presidents, and seven visits by the prime ministers of the two governments (Le 2017: 77-78). The leadership of the two countries articulated to the Chinese and Vietnamese publics the slogan "bury the past, open up the future" and promoted the sixteen-word principle of becoming "good neighbours, good friends, good comrades, and good partners" (Nguyen Phuong 
Hoa 2006: 42). "Always taking the big picture into consideration" was considered the most important principle for Vietnam to follow in managing its relations with China (Le 2017: 79).

In May 1998, the CPV Politburo adopted Resolution no. 13, which emphasised normalising relations with China as one of the country's top foreign policy goals. On 27 August 1998, the Vietnamese National Assembly also voted to remove a reference to China as a "direct and dangerous threat" from the preamble of Vietnam's 1982 Constitution (Le 2017: 55). The party's Resolution no. 8 of July 2003 marked a major development in Vietnam's adjustment to the changing international relations of post-Cold War Asia (Elliott 2014: 237). The document avoids relying on the Cold War dichotomy of friends and enemies and uses the less adversarial terms 'object of cooperation' (doi tac) and 'object of struggle' (doi tuong) to provide a "more subtle and diversified approach to Vietnam's foreign policy and more flexibility to engage with former enemies" (Elliott 2014: 237). Along with their increased economic cooperation, Hanoi and Beijing reached agreements on land border disputes and the Tonkin Gulf in 2000 (Le 2017: 74-75). ${ }^{4}$ Although the maritime dispute in the South China Sea remained unresolved, these landmark achievements significantly improved Sino-Vietnamese relations. Yet, Vietnam's policy towards China in the 1990s and early 2000s, as former Vice Minister of Foreign Affairs Tran Quang Co wrote in his unpublished memoir, was a two-faced strategy of "cooperating while struggling" with China as a reciprocal response to China's similar strategy towards Vietnam (Tran 2003: 296).

As Sino-Vietnamese relations gradually warmed, the 1979 border war with China started to be downplayed in historical writing. While Vietnam's long tradition of resisting the powerful Chinese empire continued to appear in mainstream historiography in Vietnam, the 1979 war was suppressed but far from forgotten. For instance, in Understanding the Culture of Retaining the Nation, published by Vietnam's Military Institute of Humanities and Social Sciences, the official history covered the lessons learned from the resistance against the Chinese dynasties to the great victory against the United States but stopped short of mentioning the 1979 border war (Vien Khoa Hoc Xa Hoi Nhan Van Quan Su 2002: 11-12). Similarly, in 2000, historian Tran Duc Cuong, director of Vietnam's Historical Studies Institute, drew diplomatic lessons from Vietnam's War of Resistance Against America without delving into the Sino-Vietnamese

\footnotetext{
${ }^{4}$ On 25 December 2000, an agreement on the delimitation of the Tonkin Gulf was finally signed in Beijing after seven rounds of negotiations at the government level and eighteen rounds at the joint working group level that began in 1994. The Vietnam-China land border delimitation treaty was signed in Hanoi on 30 December of that year.
} 
conflict after 1975 (Tran 2000: 286-287). On the 55th anniversary of diplomatic relations between China and Vietnam in 2005, Nguyen Dinh Liem at the China Research Institute of Vietnam's Academy of Social Sciences (VASS) published the book Sino-Vietnamese Relations: Events in 1961-1970. It placed an emphasis on how the two countries went through a very tough period (the Cultural Revolution in China and the War of Resistance Against America in Vietnam) and yet the two parties and peoples were able to maintain their friendship, cooperation, and mutual assistance (Nguyen Dinh Liem 2006: 12). As Tuong Vu (2014: 39) observes, during this period, "victories against France and America continue to be proudly commemorated while the Party seeks to erase the 1979-1989 Sino-Vietnamese conflict from public memory”.

Yet, while improving relations with Beijing topped the agenda of the reformist Vietnamese government under General Secretary Nguyen Van Linh and Prime Minister Vo Van Kiet, the discourse of the 1979 border war had not changed at the academic level and continued to blame the Chinese for seriously undermining the traditional Sino-Vietnamese friendship. In response to China's claim that its invasion of Vietnam in 1979 had been in self-defence, Vietnamese military historians called out the Chinese narratives for bleaching the history of the war by disguising the truth of China's belligerence (Nguyen et al. 1996: 85-86). They reproduced the state-sponsored history of the great victory of the Vietnamese people and army against China's massive invasion in a heroic narrative that described Vietnam as easily destroying fourteen Chinese regiments in the first four days of war. At the same time, they were allowed to openly write about the massive destruction of the North by the invading Chinese troops (Nguyen et al. 1996: 87-89) in an attempt to appeal to China for reparations.

Moreover, memories of 'the 1979 war to defend the northern border', as the Vietnamese call it, were not marginalised to the same extent in Vietnam as they were in China because the war fit neatly into the Vietnamese narrative of defending the nation against powerful China. Therefore, this narrative could be reproduced, rearticulated, and reiterated together with historical writings on China's military takeover of the Paracel Islands in 1974 from the former Republic of Vietnam and the Chinese navy's attacks on Vietnam's patrol boats in 1988 (Nguyen et al. 1996: 132-135) whenever the Vietnamese state sought to ramp up nationalist sentiment and boost its legitimacy. For instance, Tran Duc Cuong (2000: 274-284) warned of the China threat by arguing that the most important lesson that the current Vietnamese leadership should 
remember from the experiences of their ancestors was Vietnam's past resistance against foreign invaders to preserve its independence and national sovereignty.

During the period from 1991 to the early 2000s, when bilateral relations between China and Vietnam were improving steadily, maintaining a historical memory of the Sino-Vietnamese War was of little use to the Chinese state and the CCP but doing so remained highly relevant to Hanoi's political agenda. On the one hand, the heroising narrative of the Vietnamese people resisting the Chinese invasion in 1979 echoed Vietnam's collective memory of defending the country against its powerful northern neighbour for two thousand years, which is an integral part of Vietnamese nationalism. This collective memory can be used to mobilise popular support when new tensions between the two countries emerge to remind the Vietnamese people that they should not be complacent when it comes to the countries' bilateral relations. On the other hand, Hanoi's attitude towards Beijing was subject to "the politics of overattention", a concept developed by Brantly Womack (2006: 82-83) to describe the weaker power's policy towards the stronger one in an asymmetric relationship. In their bilateral relations, Vietnam has always been more attentive and proactive in response to China's actions.

\section{Vernacular Resistance against Official Narratives: 2000s to the Present}

Since the mid-2000s, bottom-up commemoration of the Sino-Vietnamese War has started to resist the Chinese state's suppression of war memories and the Vietnamese government's endeavour to monopolise the reproduction of memory. Such vernacular resistance against official narratives of war has emerged in a context in which China and Vietnam seem to have found a modus vivendi to manage their territorial conflicts. The Sino-Vietnamese Joint Statement in 1999 called for "long-term stability, facing the future, good-neighbourliness and friendship, and comprehensive cooperation" between the two countries (Renmin Ribao 1999: 1). From 1999 to 2010, Vietnam and China made tremendous progress in their land border demarcation. Increasing cross-border trade transformed the border region from a confrontational frontline to a space of abundant economic opportunity (Vu 2010: 6). In 2009, China and Vietnam concluded their agreements and ended thirty-five years of negotiation. Neither side expected to resolve the maritime border dispute anytime soon, but both appeared to believe that the other side also wanted to create a stable international environment in order to concentrate on their respective 
economic development (Cheng 2011: 387). In the context of tensions over the South China Sea and rising cyber nationalism, since the 2000s, bottom-up memorialisation has surfaced in both countries. Whereas the Vietnamese government has decided to harness the spontaneous memorialisation of the war, Beijing remains reluctant to endorse commemoration on a national level.

\section{The Re-emergence of War Memories in China}

In China, the re-emergence of war memories has had more to do with some profound changes that have taken place in Chinese society than the fragility of Sino-Vietnamese relations. Most importantly, veterans have advocated for greater social recognition of their sacrifice during the war in support of their appeal for better retirement benefits. Many soldiers drafted into the army in the 1980s spent the majority of their service time fighting the long war with Vietnam and therefore failed to acquire the necessary skills or gain enough education to maintain a decent standard of living after discharge. Some of them were lucky enough to have landed jobs in staterun enterprises yet soon lost their positions as a result of the massive layoffs associated with privatisation that began in the mid-1990s (Johns 1995: 930-931). Soldiers from rural areas who failed to secure an urban job and those who were disabled were particularly vulnerable to economic difficulties (Hunan Provincial Government 2001: 33). In short, a decade after the cessation of animosity between China and Vietnam, many of those who had served in the war had failed to catch up economically or benefit from the market-oriented reform.

Veterans have stood up for their rights through collective action. In 2002, 630 veterans visited the Petition Office of Political Department of the PLA, which is the institution in charge of receiving complaints and appeals from military personnel and veterans. The number rose to 825 in 2003 and 2089 in 2004 (Xue and Wu 2012: 7-12). Those who could not afford to travel to Beijing protested to the local government instead. On 12 September 2013, more than 1000 veterans assembled in front of the Civil Affairs Department of Yunnan Province to ask for higher pensions (Radio Free Asia 2013). Many veterans wore their old uniforms from the 1980s, thereby reminding both the government and the public of the Sino-Vietnamese War. According to official Chinese statistics, the conflict caused 6900 deaths and 15,000 injuries on the Chinese side (Zhang 2005: 866-867), affecting a small fraction of the total population. The veteran 
activists had to refresh people's memories of the war in order to marshal popular support for their cause.

Places that were once battlefields also became important sites for Chinese veterans to commemorate the war and call for greater social recognition. Since 1999 (the 20th anniversary of the 1979 border war), veterans from Guangxi and other provinces have organised annual commemorations of the war in Pingxiang on 17 February, the anniversary of the date on which the war broke out. They wear their old uniforms, visit cemeteries, and assemble at the Friendship Pass, which is the historical mountain pass between the two countries. When the group grow to reach a considerable size, it becomes a concern for the local administrators, but they are actually sympathetic to the veterans' cause because the sacrifice of the people living in border communities during the war have not been properly recognised either. The officials, however, have worried that the commemoration would provoke protest. Negotiations between the veterans and the local government yield to carefully planned and closely monitored forms of commemoration. In 2014, more than 4000 veterans arrived in Pingxiang on the 35th anniversary of the war. The local government provided a venue for the dinner party that was held that day for free in the best hotel in town and paid for their food. In exchange, the veterans agreed to limit the size of the ceremony held at the Friendship Pass (Anonymous interview 2015).

Increased access to the internet has also provided opportunities for both veterans and young people curious about China's recent past to reconstruct memories of the 1979 border war. Chinese nationalists utilise the internet as "a communication center, organizational platform, and execution channel to promote the nationalistic cause" that is not always in line with government policy. Cyber-nationalism has been growing in China due to its "inherent grassroots appeal" and the wide reach of online technology (Wu 2007: 3). In 2001, a Tsinghua University student named Jiang Lei set up a website called Tiexue, which translates to 'blood and iron', adopted from Bismarck's Blood and Iron speech. The website focuses on the history of and contemporary issues related to the Chinese military and foreign relations.

In 2004, Jiang created a company with the same name and successfully listed it in 2015, indicating the website's popularity. On its discussion forum, the 'self-defensive counterattack against Vietnam' is a popular topic, and it is where veterans and their children post their recollections related to the war. ${ }^{5}$ On the anniversary of the outbreak of the war each year, the

\footnotetext{
${ }^{5}$ http://mil.tiexue.net/tag junlv 0db1f6143d6e667191a61a739ac75ea1 1.html.
} 
forum becomes a venue for the voices of people who are discontent with the lack of an official and national commemoration of the war. ${ }^{6}$ In 2010, a young military enthusiast nicknamed Baqiang ('eight guns') established a website called 'War Memorial of the Self-defence against Vietnam' in response to the absence of a physical memorial of the war. Baqiang set an ambitious goal of recording the names, photos, and tombstones of all the Chinese soldiers who fell during the war. By March 2019, the website had collected 10,663 entries, which greatly exceeded the officially released number of casualties. ${ }^{7}$ The rise of the internet as a social sphere relatively independent of the government has made memorialising the war more accessible to the public.

A few veterans have gone so far as to openly question China's motives for entering a decade-long confrontation with an important neighbour, although they have had to publish their works outside of mainland China. In 2010, Ni Chuanghui, a 1979 border war veteran and military journalist, published a two-volume history of the Sino-Vietnamese conflict in Hong Kong. The book criticises Deng Xiaoping's decision to engage in war as "hasty", "chauvinist", and "illegitimate" (Ni 2010: 983). China's invasion of a neighbouring country and its support of the notorious Khmer Rouge, according to the author, dealt a heavy blow to China's prestige in Asia. He further denounces Deng for launching the war without the endorsement of the People's Congress, indicating his ignorance of the people' will (Ni 2010: 983-988). This publication of a critical work outside of mainland China by a former serviceman reflects a current trend in Chinese society towards gaining a more diverse understanding of the war and is also an example of the state's ongoing censorship of war-related publications.

Beijing has had to cautiously accommodate the public's re-remembrance of the 1979 war while containing the impact of bottom-up forms of commemoration. Veteran activism and internet activism have successfully exerted pressure on the government to recognise the war but has not led to national forms of commemoration. Since the 2000s, the Sino-Vietnamese War has reappeared in textbooks, but as the official Chinese perspective on the war has not changed, the Vietnamese are depicted as ungrateful backstabbers (Qu and Zhong 2012: 194-199; Xie 2009: 257-272). However, unrestricted research and publications on or artistic representations of the war remain impossible. If a book manuscript argues that Beijing launched the war to strengthen

\footnotetext{
${ }^{6}$ See for example Fennu (2016).

${ }^{7}$ http://www.79china.org/about/index.asp?id=35.
} 
its ties with Washington or elaborates on China's support of the Khmer Rouge, the publisher will censor all related chapters. ${ }^{8}$

In December 2017, the movie Fang Hua (Feng 2017), a coming-of-age drama that depicts the lives of a group of idealistic adolescents in a PLA art troupe in the 1970s and 1980s, was released in China and became a blockbuster. The movie includes a six-minute scene showing the long-forgotten Sino-Vietnamese War and was the first direct depiction of the war in Chinese theatres since the normalisation of Sino-Vietnamese relations in 1991 (Buckley 2018). The way it portrays the war, however, reflects the compromise that the director made in order to pass the stringent art censorship. Instead of explicitly showing China fighting against Vietnam, the caption describes it as a war that broke out on China's 'southwestern border', and there are almost no scenes featuring Vietnamese soldiers (Feng 2017). Therefore, audiences without any prior knowledge of the history of this war would not be able to tell from the film whom the Chinese soldiers fought.

\section{The Utility of War Memories for the Vietnamese State}

In the past decade, the Vietnamese government's attitude towards memories of the 1979 war has shifted from a managed suppression to an active promotion of their public commemoration. This change can be attributed to the escalation of territorial disputes in the South China Sea and the rising anti-Chinese sentiment that has been manifesting in mass protests and violent riots. A turning point happened in the CPV's China policy in 2003 when clashes of national interests over maritime boundaries eclipsed their ideological affinity. In that year, as Carlyle Thayer (2016: 210) observes, "the CPV made the momentous decision to downgrade socialist ideology as the prime basis for conducting relations with China ... in part because of the persistence of maritime disputes in the South China Sea, and new opportunities in relations with the United States following normalization in 1995 and the conclusion of a bilateral trade agreement in 2001". Sino-Vietnamese negotiations on the maritime dispute in the South China Sea failed in 2006. On 2 February 2007, the CPV Central Committee passed a resolution on "Vietnam's maritime strategies to 2020 " in which one of the strategic objectives was to make Vietnam a maritime power (Nguyen 2014: 121). While attempting to prevent a military confrontation with China, Hanoi has also harnessed the rising anti-Chinese sentiment felt in Vietnamese society

\footnotetext{
${ }^{8}$ According to Niu (2010), an editor asked him "not to write a single word about Chinese-Khmer Rouge relations.
} 
since the territorial dispute in the South China Sea turned into an open conflict in the summer of 2014 (Le 2017: 128).

With the help of cyberspace and two decades of economic reform, anti-Chinese nationalism in Vietnam has been spreading since the mid-2000s, reflecting a pattern similar to the rise of cyber nationalism in China. Early online activism facilitated the mobilisation of the first anti-China protests in late 2007 and early 2008 in Hanoi and Ho Chi Minh City, respectively, which were triggered by the Chinese government's announcement that it would create a new district out of the Paracel and Spratly Islands (Vu 2014: 42). Tuong Vu traces the origins of this anti-China movement to the birth of the "bauxite group" as an influential voice in the rapidly flourishing virtual networks of the educated Vietnamese public. The bauxite group grew due in part to the support it gained from influential public intellectuals and retired highranking officials (Vu 2014: 43-44). This group created a website for its Institute of Development Studies and has published numerous critical analyses of government policies and submitted petitions on a wide range of issues, including policies towards China and territorial disputes in the South China Sea. Doing so “exposed the [CPV]'s vulnerabilities, particularly its ideological dependence on China" (Vu 2014: 44-45), which was the precursor to more intellectuals becoming willing to criticise Hanoi for being soft on China.

Blogger and writer Pham Viet Dao is arguably the most vocal critic of Hanoi for appeasing China and suppressing protests against China (Rfi Radio 2019). In March 2014, Dao was sentenced to imprisonment for 15 months on charges of "abusing democratic freedoms to harm the interests of the State" by posting online articles that "distorted, vilified, and smeared the senior leaders" (Viet Bao 2014). The government could not tolerate Dao's posting of sensitive 'historical facts' about the border war with China from 1979 to 1989 and exposing Hanoi's appeasement of Beijing over their territorial disputes (Dang 2019). After being forced to close down his blog (nvphamvietdao5), Dao was able to self-publish his 900-page book in Vietnamese titled Vi Xuyen and Sino-Vietnamese Affairs in 2019, detailing the heroic sacrifices made by Vietnamese soldiers during the gruesome battles at Vi Xuyen from 1984 to $1988 .{ }^{9}$ The book is widely discussed online, especially around the anniversary of the war (Dang Van Sinh 2019; Cau Lac Bo Le Hieu Dang 2020). The shift in the Vietnamese government's attitude to

\footnotetext{
${ }^{9}$ See https://baotiengdan.com/2019/12/01/vi-xuyen-va-the-su-viet-trung-giai-ma-cuoc-chien-tranh-co-nguy-co-bi-bo-quenvixuyen-va-the-su-viet-trung-giai-ma-cuoc-chien-tranh-co-nguy-co-bi-bo-quen/.
} 
Dao signals its increased tolerance of non-state-sanctioned publications that honour the sacrifices made by ordinary Vietnamese rather than glorify the CPV or the Vietnamese state, largely because such narratives are compatible with the government's enhanced willingness to confront China over their maritime disputes.

As the South China Sea dispute became heated in 2014, Vietnamese historians and stateaffiliated research institutes became determined to push for more writing and publications on the 1979 border war and to include this event in high school history textbooks. In 2011, Nguyen Dinh Liem, an expert on China from the China Research Institute at VASS, published his analysis of the future of Sino-Vietnamese relations to 2020, in which he argued that China's expansionist ambitions in the South China Sea - a crucial factor in maintaining China's superpower status - would strain Sino-Vietnamese relations, and he predicted that if the ultranationalists came to dominate Beijing's decision making, "the history of Deng Xiaoping ordering an attack on Vietnam would repeat itself' (Nguyen 2001: 49-50). Historian Vu Duong Ninh, one of the authors of Vietnam's grade 12 history textbook, revealed to local television network TV1 his dissatisfaction with the Vietnamese government's decision to reduce the four-page history of the Sino-Vietnamese War in the proposed original manuscript to only eleven lines. He also complained that the final draft did not call out China as 'the aggressor' (VNExpress 2016).

Vietnam's conflict with China in the South China Sea worsened in 2017 as China decided to fortify some islands under its control. The Vietnamese academy's pressure on the government to lay bare 'the Chinese aggression' in 1979 grew stronger, and the Vietnamese government was criticised for not being 'historically objective' about the border war with China. On 17 February 2017, online media outlets - particularly VNExpress - published detailed accounts of the war using documentary video clips and interviews with Vietnamese historians, eyewitnesses, survivors, and members of the 1979 war veteran associations (VNExpress 2017a).

In the summer of 2017, the Vietnamese government permitted a group of Vietnamese historians led by Tran Duc Cuong to officially reintroduce 'China's war of aggression on Vietnam in 1979' into Vietnam's highly publicised series of Vietnamese history textbooks (VNExpress 2017b). Although the narrative was nothing new, the more detailed reproduction of the 1979 border war and the publicity stunt during the launching of the new series served the purpose of Hanoi's pivot to the United States against China's new assertiveness in the South China Sea. Notably, in Volume Fourteen of the series, nine pages (pages 351 to 359) detailed the 
events leading up to the 1979 border war by clearly depicting China as the aggressor. While Vietnamese students had learned about heroes like Nguyen Van Troi in their lessons on the war against the United States, no Vietnamese heroes had been named in previous history textbooks' depictions of the 1979 war. Tran Duc Cuong and Nguyen Manh Ha, former director of party history, gave interviews with local Vietnamese media and reached out to academics in the United States and elsewhere to publicise the series. Tran told a local media outlet: "Vietnamese people, of course, need to know about the history of this war, but we want the world to know the nature of the Chinese war of aggression against Vietnam" (Thoi Moi 2018). To avoid provoking China, Tran said at a national workshop held on the 40th anniversary of the war that commemorating the conflict was "not to delve into hatred but to repeat a historical truth" (Thu 2019).

Not surprisingly, the 40th anniversary of the war in 2019 saw an outpouring of commemorative products, speeches, and rituals that had the strong support of the Vietnamese government. On 13 February, state-run television channel VTC1 showed a documentary film titled The Northern Border Defence Battle commemorating the Vietnamese people's bravery and revolutionary tradition of defending the northern border. This was followed by an interview on 15 February with Vu Tang Bong, a senior expert at Vietnam's Institute of Military History, who reiterated the heroising narrative of the Vietnamese people's war to defend the Fatherland against the aggression of Chinese invaders (VTC1 2019). Notably, on the same day, VASS and Vietnam's Association of Historical Sciences held a well-publicised conference on "The Battle to Defend the Northern Border of [our] Nation: Looking Back 40 Years Later (1979-2019)" (Thu 2019). All of these efforts (visibly guided by the hand of the Vietnamese state) were designed to present a 'just cause' narrative that reflected Vietnam's history of repelling foreign aggressors and perpetuated a historically familiar tradition of highlighting the noble and meaningful sacrifice of Vietnamese people in defence of the nation against the northern threat.

The amount of time and energy that Vietnamese academics and state organs have devoted to remembering the 1979 war with China are in sync with the changing tempo of SinoVietnamese relations. It is also consistent with Vietnam's desire to manage anti-Chinese sentiment at home and to utilise memories of war to support Vietnam's foreign policy pivots towards extra-regional powers (e.g. the Soviet Union during the Cold War and the United States currently) to cope with the Chinese threat. As the Sino-Vietnamese conflict over the South China Sea escalates, the Vietnamese government is promoting historical research into the 1979 war 
with China and state-run media outlets and social media users are amplifying the memorialisation of war as Vietnamese society becomes increasingly anti-China. The writing of history remains a nationalist project in Vietnam where the mistakes (including the mass persecution of Chinese residents) and the failures of the country's leaders to anticipate China's 1979 invasion have been either purposely forgotten or simply suppressed. Since the South China Sea conflict intensified in 2014, the Vietnamese party-state has embraced annual commemorations of the 1979 border war with China and historical writings about the conflict have aimed at providing Vietnamese youth with a patriotic education on the Chinese threat. In this process, the Vietnamese state has ensured that no other actors besides the party-state dominate the space of memorialising the 1979 war.

\section{Conclusion}

How China and Vietnam remember, forget, and re-remember the Sino-Vietnamese War reflects not only the fluctuations in Sino-Vietnamese relations but also the changing relationships between the state and society in the two countries as they undergo rapid transformations. The Chinese and Vietnamese governments both continue to try to create highly selective memories of the war. Beijing has turned a blind eye to the CCP's history of buttressing the genocidal regime of the Khmer Rouge, whereas Hanoi aims to suppress stories regarding Vietnam's mistreatment of ethnic Chinese and the military miscalculations that took place in the beginning of the Third Indochina War in 1978-1979. How China and Vietnam remember and downplay the SinoVietnamese War points to the larger picture of the sensitivity of bilateral relations to historical memory in Asia. In particular, historical memory shapes how a country perceives external threats and opportunities. Meanwhile, historical memory is created, suppressed, and re-created as international relations evolve.

While political elites continue to wield significant control over its utility for domestic and foreign policy purposes, historical memory remains a negotiated and contested site between the state and society in both China and Vietnam. Despite Beijing and Hanoi retaining considerable repressive capabilities, they have had to accommodate the vernacular resistance to the government-sanctioned narratives of the Sino-Vietnamese War. The Vietnamese government has allowed prominent Vietnamese scholars to write the Sino-Vietnamese War into history textbooks 
and publications available to the general public. Meanwhile, veterans and young people who are devoted to nationalist causes in both countries have made use of the internet to refresh their respective society's memories of the war. The formation and recreation of historical memory with regard to the Sino-Vietnamese War are increasingly the result of interactions and negotiations between the state and the public, instead of a process monopolised by the political authorities.

\section{Acknowledgements}

We are grateful for the insightful comments offered by our anonymous peer reviewers. Their generosity and expertise have improved this study in innumerable ways. All remaining errors are entirely our own responsibility.

\section{References}

Alley, Rewi. 1980. Refugees from Viet Nam in China. Beijing: New World Press.

Bislev, Ane. 2014. "Nationalist netizens in China: Online historical memory." Journal of China and International Relations 2(1): 117-136.

Buckley, Chris. 2017. "Touching on History, a Chinese Film May Have Been Burned by It." The New York Times, 25 September. Available at: https://www.nytimes.com/2017/09/25/world/asia/china-movie-youth.html (accessed 6 March 2018).

Butterfield, Fox. 1979. "4 Provinces Invaded: Thrust Reported All Along Border-Peking Says Move Is Retaliatory." The New York Times, 18 February. Available at: https://www.nytimes.com/1979/02/18/archives/4-provinces-invaded-thrust-reported-all-alongborderpeking-says.html (accessed 29 July 2020).

Cau Lac Bo Le Hieu Dang. 2020. "Tuong niem 41 nam cuoc chien chong xam luoc Trung Quoc o Bien gioi Phia Bac" [41st commemoration of China's invasion of the northern border], vanviet.info, 16 February, available at: http://vanviet.info/van-de-hom-nay/tuong-niem-41-namcuoc-chien-chong-xm-luoc-trung-quoc-o-bin-gioi-pha-bac/ (accessed 17 May 2020).

Chen, Baoyun. 1983. "Yin 'gaoshan xia de huahuan' er xiangdaode" [Reflection on Wreaths at the Foot of the Mountain]. Shandong Literature Monthly Magazine 2: 77-78.

Chen, King C. 1987. China's War with Vietnam: Issues, Decisions, and Implications. Stanford: Hoover Institute Press. 
Cheng, Joseph Y.S. 2011. "Sino-Vietnamese relations in the early twenty-first century." Asian Survey 51(2): 379-405.

Connerton, Paul. 2008. "Seven types of forgetting.” Memory Studies 1(1): 59-91.

Dang, Van Sinh. 2019. “'Vi Xuyen \& The Su Viet - Trung' Gac Ma Cuoc Chien Tranh Co Nguy Co Bi Bo Quen" ['Vi Xuyen and the Sino-Vietnamese affairs' exposed the war in danger of being forgotten], vanviet.info, 23 December. Available at: http://vanviet.info/nghien-cuu-phebinh/vi-xuyn-the-su-viet-trung-giai-m-cuoc-chien-tranh-c-nguy-co-bi-bo-qun/ (accessed 17 May 2020).

Denton, Kirk A. 2014. Exhibiting the Past: Historical Memory and the Politics of Museums in Postsocialist China. Honolulu: University of Hawaii Press.

Duiker, William. 1986. China and Vietnam: The Roots of Conflict. Berkeley: Institute of East Asian Studies, University of California.

Elliott, David W.P. 2014. Changing Worlds: Vietnam's Transition from Cold War to Globalization. Oxford: Oxford University Press.

Fang Hua [Youth]. 2017. Directed by Xiaogang Feng. Beijing: IM Global, DVD.

FCDA, no. 1-2-455-13. 1979. "Zhonggong Qinzhou diqu weiyuanhui guanyu xuexi Dongzhong gongshe duiYue ziwei huanji zhandou zhong mofan shiji de jueding" [CCP Qinzhou District Committee's decision to learn from the model performance of Dongzhong Commune during the self-defensive counterattack against Vietnam], 22 May, Fangcheng District Archives, Fangchenggang, Guangxi, China, 38-44.

Fennu Dacaidao ['Angry chopper']. 2016. "Suiyue youyou zhonghun yongcun: jinian dui Yue ziwei fanjizhan 37 zhounian" [Years have passed but loyal spirits last forever: Commemoration of 37th anniversary of the self-defensive counterattack against Vietnam], 17 February, posted by the Tiexue forum. Available at: http://bbs.tiexue.net/post_11288207_ 1.html (accessed 27 February 2019).

$\mathrm{Fu}$, Jianren. 1991. Keyi gongkai de conglin mizhan [A secret war in the jungle that can be published now]. Beijing: Jiefangjun wenyi chubanshe.

Giebel, Christoph. 2007. "Revolution, war, and memory in contemporary Viet Nam." In Ruptured Histories: War, Memory, and the Post-Cold War in Asia, edited by Sheila Miyoshi Jager and Rana Mitter, 307-321. Cambridge, MA: Harvard University Press.

Grossheim, Martin. 2018. "Đổi mới in the classroom? The portrayal of national and world history in Vietnamese textbooks." Sojourn: Journal of Social Issues in Southeast Asia 33(1): 147-180. 
Guo, Ming. 1992. Zhongyue guanxi yanbian sishinian [The evolution of Sino-Vietnamese relations over forty years]. Nanning: Guangxi renmin chubanshe.

Hood, Steven J. 1992. Dragons Entangled: Indochina and the China-Vietnam War. Armonk: M.E. Sharpe.

Hunan Provincial Government. 2001. "Hunansheng renmin zhengfu bangongting guanyu tuoshan jiejue guoyou qiye xiagang geming shangcan junren jiben shenghuo baozhang he zaijiuye youguan wenti de tongzhi" [Notice of people's government of Huanan province about properly solving the problem of keeping the basic living standard of laid-off disabled veterans and helping them with employment], Hunan zhengbao [Administrative bulletin of Hunan Province] 22: 33 .

Jiangsu renmin chubanshe. 1979. Ziwei huanjizhan yingxiong shiji [Heroic stories during the self-defence war]. Nanjing: Jiangsu renmin chubanshe.

Jin, Hui, Huisheng Zhang, and Weiming Zhang. 1990. Zhongyue zhanzheng milu [The secret history of the Sino-Vietnamese War]. Beijing: Shidai weiyi chubanshe.

Johns, Deborah Kay. 1995. "Reforming the state-enterprise property relationship in the People's Republic of China: The corporatization of state-owned enterprises." Michigan Journal of International Law 16(3): 911-940.

Khoo, Nicholas. 2011. Collateral Damage: Sino-Soviet Rivalry and the Termination of the SinoVietnamese Alliance. New York: Columbia University Press.

Kwon, Heonik. 2008. Ghosts of War in Vietnam. Cambridge: Cambridge University Press.

Le, Hong Hiep. 2017. Living Next to the Giant: The Political Economy of Vietnam's Relations with China under Doi Moi. Singapore: ISEA - Yusof Ishak Institute.

Li, Cunbao. 1982. Gaoshan xia de huahuan [Wreaths at the foot of the mountain]. Jinan: Shandong renmin chubanshe.

Luu, Loi Van. 2006. 50 Years of Vietnamese Diplomacy, 1945-1995 (English edition). Hanoi: The Gioi Publishers.

Malarney, Shaun Kingsley. 2001. "The fatherland remembers your sacrifice: Commemorating war dead in North Vietnam." In Country of Memory: Remaking the Past in Late Socialist Vietnam, edited by Hue-Tam Ho Thai, 46-76. Berkeley: The University of California Press.

Mertha, Andrew C. 2014. Brothers in Arms: Chinese Aid to the Khmer Rouge, 1975-1979. Ithaca: Cornell University. 
Middleton, Drew. 1979. “A Classic Military Operation: China's Drive on a Wide Front in Vietnam Leaves Hanoi Guessing About Main Focus and Objective." The New York Times, 18 February: 1.

Ngo, Thi Thanh Tuyen. "Lich Su Chien Tranh Chong Khome Do Xam Luoc Vietnam tren huong Tay Nam (5/1975-12/1978)" [A history of war against the Khmer Rouge aggression on Vietnam in the Southwest, 5-1975-12/1978]. MA diss., National University of Vietnam, 2018.

Nguyen, Dinh Liem. 2001. "Trien vong quan he Trung-Viet trong thap nien thu hai cua the ky XXI" [The trend of Sino-Vietnamese relations in the second decade of the $21^{\text {st }}$ century]. Nghien cuu Trung Quoc [China Studies Review] 11(123): 49-50.

Nguyen, Dinh Liem. 2006. Quan He Viet Nam - Trung Quoc: Nhung Su Kien 1961-1970 [SinoVietnamese relations: Events in 1961-1970]. Hanoi: Nha Xuat Ban Khoa Hoc Xa Hoi.

Nguyen, Huy Toan, Bong Tang Vu, Thuc Huy Nguyen, Binh Viet Nguyen, and Duc Minh Nguyen. 1996. Su That Ve Nhung Lan Xuat Quan Cua Trung Quoc va Quan He Viet-Trung [The truth of China's military interventions and the Sino-Vietnamese relations]. Da Nang: Nha Xuat Ban Da Nang.

Nguyen, Ngoc Truong. 2014. Ve Van De Bien Dong [On the East Sea]. Hanoi: Nha Xuat Ban Chinh Tri Quoc Gia-Su That.

Nguyen, Phuong Hoa. 2006. "Buoc phat trien cua quan he Viet - Trung qua cac chuyen tham cap cao" [The development of Sino-Vietnamese relations through high-level visits. Nghien Cuu Trung Quoc [China Studies Review] 6(70): 42-49.

Nguyen, Van Hong. 2013. Cuoc Chien Tranh Bat Buoc [Compulsory war]. Hanoi: Nha Xuat Ban Quan Doi Nhan Dan.

Ni, Chuanghui. 2010. Shinian Zhongyue zhanzheng [Ten years of Sino-Vietnamese War]. Hong Kong: Tianxingjian chubanshe.

Niu, Jun. 2010. Zhonghua renmin gongheguo duiwai guanxishi gailun [Introduction to the history of the foreign relations of the People's Republic of China, 1949-2000]. Beijing: Peking University Press.

Niu, Jun. 2013. Lengzhan yu Zhongguo waijiao juece [The Cold War and Chinese foreign policy making]. Beijing: Jiuzhou chuban she.

Nong, Wenke. 2015. Zhongguo gongchandang Pingxiang lishi di 2 juan (1949-1991) [History of the CCP in Pingxiang, 1949-1991, vol. 2]. Nanning: Guangxi renmin chubanshe.

O’Dowd, Edward C. 2007. Chinese Military Strategy in the Third Indochina War: The Last Maoist War. London: Routledge. 
Pengpai Xinwen. 2017. "Tanfang ZhongYue bianjing dilei cun" [A visit of the landmine village in the Sino-Vietnamese border], 7 December. Available at: http://m.thepaper.cn/newsDetail_forward_1893592 (accessed 15 May 2020).

Phan, Huy Le. 1979. "Hon Hai Ngan Nam Dau Tranh Chong Chinh Sach Banh Truong Cua Bon Phong Kien Trung Quoc" [More than two thousand years of resistance against the expansionist policies of feudal China]. In Phe phan Chu nghia Banh truong va Ba quyen Nuoc lon cua Gioi Cam quyen Phan dong Bac Kinh [Review of the Beijing Reactionary Leadership's Expansionism and Hegemony], edited by Pham Nhu Cuong, 147-159. Hanoi: Nha Xuat Ban Khoa Hoc Xa Hoi.

Phu Thu Tuong (PTT), h.s. 16327. 1979. "Bao cao cua Van phong PTT ve dot di cong tac len cac tinh bien gioi phia Bac va nhung viec can lam ngay de giai quyet hau qua chien tranh sau khi Trung Quoc rut nam 1979" [Report of Prime Minister's Office about the visit to border provinces in the North and tasks to be immediately fulfilled to address the impact of war after China withdrew (their troops) in 1979], National Archive Center III, Hanoi, Vietnam, 1-76.

Phu Thu Tuong (PTT), h.s. 16381. 1980a. "Quyet dinh cua Hoi Dong Chinh Phu ve viec giao ke hoach san sang dong vien phuc vu nhu cau quoc phong khi co chien tranh" [Directive of the Government Council about planning and readiness to meet the need of national defence when war breaks out], 11 February, Vietnamese National Archives Center III, Hanoi, Vietnam, 4.

Phu Thu Tuong (PTT), h.s. 16381. 1980b. "Quyet dinh cua Hoi Dong Chinh Phu ve cong tac tuyen quan dot II nam 1980" [Deputy Prime Minister To Huu, Directive No. 333-CP about the task of military conscription in Round II in 1980], Vietnamese National Archives Center III, Hanoi, Vietnam, 5-9.

Qu, Xing, and Longbiao Zhong. 2012. Dangdai Zhongguo waijiao [Contemporary Chinese diplomacy]. Beijing: Zhongguo renmin daxue chubanshe.

Quinn-Judge, Sophie. 2006. "Victory on the battlefield; isolation in Asia: Vietnam's Cambodia decade, 1979-1989." In The Third Indochina War: Conflict between China, Vietnam, and Cambodia, 1972-1979, edited by Odd Arne Westad and Sophie Quinn-Judge, 207-230. New York: Routledge.

Quoc Hoi (QH), h.s. 2354. 1978. "Bao cao cua Thu Tuong Pham Van Dong truoc ky hop thu tuQuoc hoi Khoa VI, ngay 23-12-1978 tai Hoi Truong Ba Dinh Hanoi (Chep Tu Bang ghi am)" [A report by Prime Minister Pham Van Dong before the fourth session of the National Assembly's sixth plenum on December 23, 1978], National Archives Center III, Hanoi, Vietnam, 1-25.

Quoc Hoi (QH), h.s. 2374. 1979a. Truong Chinh. "Bao cao cua Uy ban thuong vu Quoc hoi" [Truong Chinh, Report of the Standing Committee of the National Assembly], 24 May, National Archives Center III, Hanoi, Vietnam, 1-4.

Quoc Hoi (QH), h.s. 2374. 1979b. "Bao cao cua Uy ban thuong vu Quoc hoi" [Report of the Standing Committee of the National Assembly], May, National Archives Center III, Hanoi, Vietnam, 5-12. 
Quoc Hoi (QH), h.s. 2374. 1979c. Dai Tuong Vo Nguyen Giap [General Vo Nguyen Giap]. "Bao cao cua Hoi Dong Chinh phu ve thang loi vi dai cua hai cuoc chien tranh bao ve To quoc va nhiem vu cua toan dan va toan quan ta truoc tinh hinh moi" [Report of the Government Council about the great victory of the two wars to defend our motherland and the tasks of our people and army in the new situation], National Archives Center III, Hanoi, Vietnam, 13-99.

Radio Free Asia. 2013. "Shangqian duiYue ziwei fanjizhan canhan laobing zai Kunming qingyuan" [More than a thousand veterans of the counterattack against Vietnam petition in Kunming], 13 September. Available at: https://www.rfa.org/mandarin/yataibaodao/renquanfazhi/hc-09132013150540.html (accessed 9 March 2019).

Renmin ribao [People's Daily]. 1999. “Zhongyue lianhe shengming” [Sino-Vietnamese Joint Statement], 28 February.

Rfi Radio (An interview with Phạm Viết Đào). 2019. "Trung Quoc triet de khai thac bai hoc Chien tranh bien gioi nam 1979" [China draws lessons from the 1979 war], 8 February. Available at: http://www.rfi.fr/vi/viet-nam/20190217-viet-nam-40-nam-sau-chien-tranh-biengioi-duoi-mat-mot-cuu-chien-binh (accessed 28 December 2019).

Ross, Robert. 1988. The Indochina Triangle: China's Vietnam Policy, 1975-1979. New York: Columbia University Press.

Shi, Zhifu. 1994. Zhonghua renmin gongheguo duiwai guanxishi [History of foreign relations of the People's Republic of China]. Beijing: Beijing daxue chubanshe.

Tai, Hue-Tam Ho. 2001. "Faces of remembrance and forgetting." In Country of Memory: Remaking the Past in Late Socialist Vietnam, edited by Hue-Tam Ho Tai, 167-195. Berkeley: The University of California Press.

Thayer, Carlyle A. 2016. "Vietnam's strategy of 'cooperating and struggling' with China over maritime disputes in the South China Sea." Journal of Asian Security and International Affairs 3(2): 200-220.

Thoi Moi. 2018. "Tong chu bien Lich su VN: Chung ta muon ca the gioi biet ve chien tranh Bien gioi phia Bac" [Editor-in-Chief of Vietnamese History: We want the whole world to know about China's war of aggression], 21 August. Available at: http://thoimoi.vn/tong-chu-bien-lich-su-vnchung-ta-muon-ca-the-gioi-biet-ve-chien-tranh-bien-gioi-phia-bac-2397.html (accessed 9 March 2019).

Thu, Hang. 2019. "Bien gioi 1979: Khong khoet sau han thu, khang dinh su that lich su" [Border in 1979: Not to deepen hatred, but to confirmed historical truth], 15 February, posted by Vietnamnet. Available at: https://vietnamnet.vn/vn/thoi-su/bien-gioi-1979-khong-khoet-sau-hanthu-khang-dinh-su-that-lich-su-508104.html (accessed 24 December 2019). 
Tian, Yi. 1985. "Tan 'gaoshan xia de huahuan' de maodun chongtu" [On conflicts reflected in Wreaths at the Foot of the Mountain]. Journal of Chinese Literature 2: 35-37.

Tran, Duc Cuong. 2000. "Vai net ve ngoai giao truyen thong Viet Nam va viec phat huy nhung yeu to tich cuc trong thoi ky hien nay" [A few characteristics of Vietnam's traditional diplomacy and some useful principles for contemporary [Vietnam]. In Ngoai Giao Viet Nam Trong Thoi Dai Ho Chi Minh, edited by Bo Ngoai Giao, 273-288. Hanoi, Nha Xuat Ban Chinh Tri Quoc Gia.

Tran, Duc Cuong, Thu Cuc Thi Dinh, and Tuyet Van Thi Luu. 2017. Lich su Viet Nam. Tap 14: tu nam 1975 den nam 1986 [History of Vietnam, Vol. 14: from 1975 to 1986]. Hanoi: Khoa hoc Xa hoi.

Tran, Quang Co. 2003. "Hoi Uc va Suy Nghi” [Memory and thought] (unpublished memoir).

Truong Chinh. 1980. On Cambodia. Hanoi: Foreign Languages Publishing House.

Vien Khoa Hoc Xa Hoi Nhan Van Quan Su [Military Institute of Humanities and Social Sciences]. 2002. Tim Hieu Van Hoa Giu Nuoc Viet Nam [Understanding the culture of retaining the nation]. Hanoi: Nha Xuat Ban Quan Doi Nhan Dan.

Vien Lich Su Quan Su Viet Nam and Bo Quoc Phong [Vietnam's Institute of Military History and Ministry of Defence]. 2010. Lich su quan tinh nguyen va chuyen gia quan su Viet Nam giup cach mang Campuchia (1978-1989) [History of the Vietnamese Volunteer Army's assistance to the Cambodian Revolution (1978-1989)]. Luu hanh noi bo [internal circulation only]. Hanoi: Nha Xuat Ban Quan Doi Nhan Dan.

Viet Bao. 2014. "Phạm Viết Đào: Tam Ngung Blog" [Pham Viet Dao temporarily postpones his Blog], 25 September. Available at: https://vietbao.com/a227295/pham-viet-dao-tam-ngung-blog (accessed 17 May 2020).

Vietnam News Agency. 2019. "Northern border defense war: Victory and lessons," 15 February, posted by Vietnam Plus. Available at: https://en.vietnamplus.vn/northern-border-defence-warvictory-and-lessons/146642.vnp (accessed 24 February 2019).

VNExpress. 2016. "GS Vu Duong Ninh: SGK Dut khoat khong duoc ne tranh cuoc chien tranh bien gioi phia Bac" [History textbook for Grade 12 cannot ignore the northern border war], 21 February. Available at: https://vnexpress.net/giao-duc/gs-vu-duong-ninh-sgk-dut-khoat-khongduoc-ne-tranh-cuoc-chien-tranh-bien-gioi-phia-bac-3358153.html (accessed 25 December 2019).

VNExpress. 2017a. "Chien Tranh bien gioi- Nhung dau moc khong the lang quen" [Border war - unforgettable milestones], 17 February. Available at: https://vnexpress.net/projects/chien-tranhbien-gioi-phia-bac-nhung-dieu-khong-the-quen-3542378/index.html (accessed 25 December 2019). 
VNExpress. 2017b. "Chien tranh xam luoc cua Trung Quoc duoc dua trong sach Lich su Viet Nam" [Chinese aggression is included in Vietnamese history books], 19 August. Available at: https://vnexpress.net/thoi-su/chien-tranh-xam-luoc-cua-trung-quoc-duoc-dua-trong-sach-lich-suviet-nam-3629609.html (accessed 25 December 2019).

VTC1. 2019 "Cuoc Chien Dau Bao Ve Bien Gioi Phia Bac" [The battle to defend the northern border], 13 February. Available at: https://www.youtube.com/watch?v=NGdTfeMrDeM (accessed 25 December 2019).

Vu, Ninh Duong. 2010. Bien Gioi Tren Dat Lien, Viet Nam-Trung Quoc [The land border between Vietnam and China]. Hanoi: Nha Xuat Ban Cong An Nhan Dan.

Vu, Tuong. 2007. "Political studies and debates on Vietnamese nationalism." Journal of Vietnamese Studies 2(2): 175-230.

Vu, Tuong. 2014. "The People v. Party: Anti-China Nationalism in Contemporary Vietnam." Journal of Vietnamese Studies 9(4): 33-66.

Wang, Zheng. 2012. Never Forget National Humiliation: Historical Memory in Chinese Politics and Foreign Relations. New York: Columbia University Press.

Womack, Brantly. 2006. China and Vietnam: The Politics of Asymmetry. Cambridge: Cambridge University Press.

Womack, Brantly. 2011. "Asymmetric rivals: China and Vietnam.” In Asian Rivalries: Conflict, Escalation, and Limitations on Two-Level Games, edited by Sumit Ganguly and William R. Thompson, 176-194. Stanford: Stanford University Press.

Wu, Xu. 2007. Chinese Cyber Nationalism: Evolution, Characteristics, and Implications. Lanham: Lexington Books.

Xiao, Lu. 1984. "Ta zhenhanle dangdai daxuesheng de xinling: ji Shanghai bufen daxuesheng zuotan dianying "gaoshan xia de huahuan"' [Piercing the soul of college students: Seminar about the film Wreaths at the Foot of the Mountain by Shanghai students]. Dianying xinzuo [New Films] 6: 77-80.

Xie, Yixian. 2009. Zhongguo Dangdai waijiaoshi [Diplomatic history of contemporary China]. Beijing: Zhongguo qingnian chubanshe.

Xue, Gangling, and Youyou Wu. 2012. "Tuiyi junren guanli tizhi gaige yanjiu” [Study on reform in the management of veterans]. Faxue zazhi [Journal of Law] 7: 6-12.

Xue, Mouhong, and Jianzhang Pei. 1990. Dangdai Zhongguo waijiao [Diplomacy of Contemporary China]. Beijing: Shehui kexue chubanshe. 
Yunnan renmin chubanshe. 1979. Xixian kaige [Victorious song on the Western Front]. Kunming: Yunnan renmin chubanshe.

Zhang, Xiaoming. 2005. “China's 1979 war with Vietnam: A reassessment.” China Quarterly 184: 851-874.

Zhang, Xiaoming. 2015. Deng Xiaoping's Long War: The Military Conflict between China and Vietnam, 1979-1991. Chapel Hill: The University of North Carolina Press.

Zhao, Dingxin. 2001. The Power of Tiananmen: State-Society Relations and the 1989 Beijing Student Movement. Chicago: University of Chicago Press.

Zhongguo renmin jiefangjun 35151 budui zhengzhibu [Political Department of 35151 Unit of PLA]. 1986. Qianxian jiangshi shuxin riji chao [Selection of correspondence and diaries of soldiers on the frontline]. Hangzhou: Zhejiang wenyi chubanshe.

\section{Interviews}

Anonymous interview with two PLA veterans, 7 September 2015, Pingxiang, Guangxi, China. 